
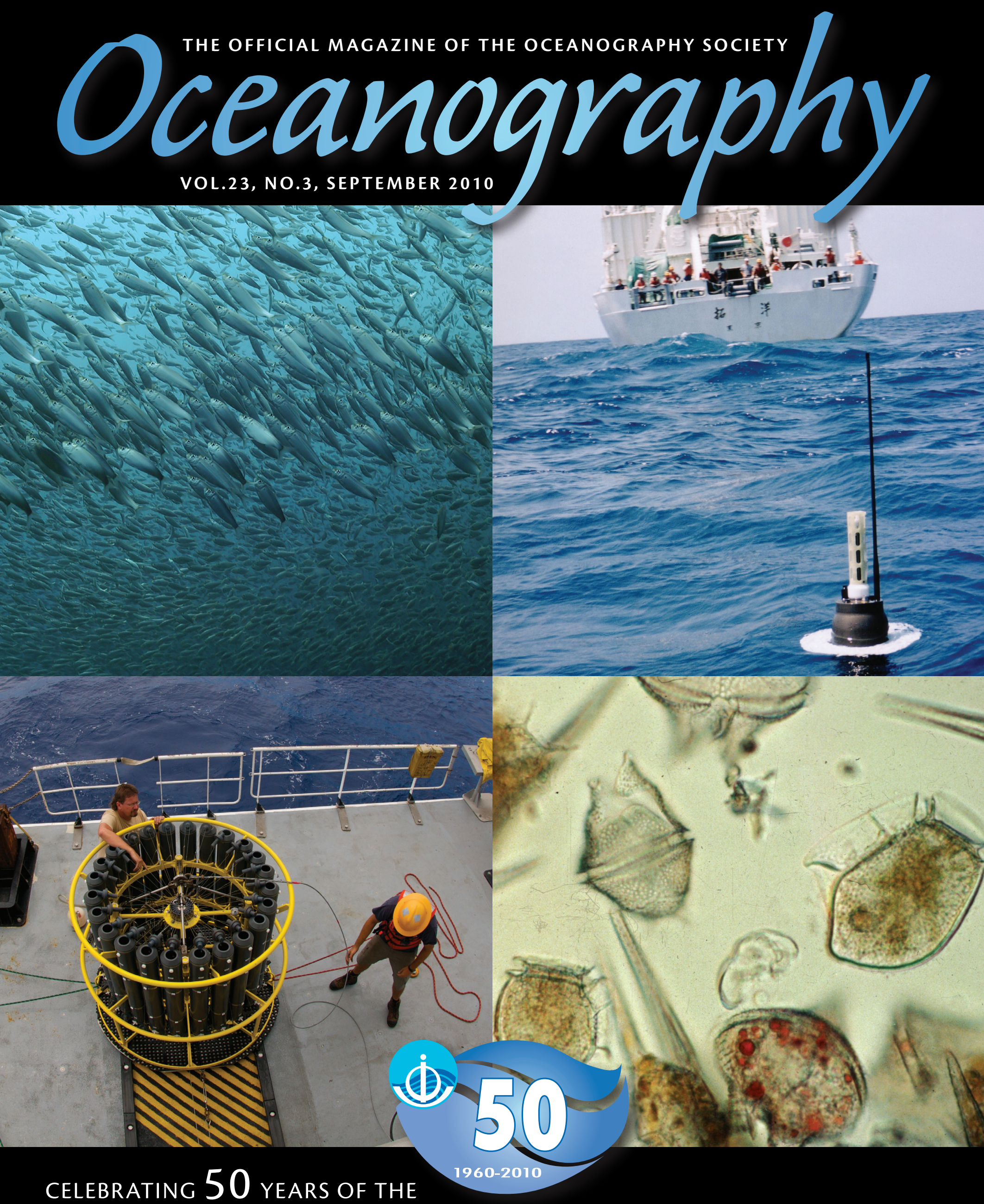

\title{
INTERGOVERNMENTAL OCEANOGRAPHIC COMMISSION
}

